\title{
THE ENTREPRENEURIAL PROFILE OF THE MACEDONIAN AGRO-ENTREPRENEUR
}

\author{
Tošo Kostadinov \\ ${ }^{1}$ Institute of Animal Science, Ss. Cyril and Methodius University in Skopje, \\ Blvd. Ilinden 92a, Skopje, Republic of North Macedonia \\ tosokostadinov@gmail.com
}

\begin{abstract}
A b s t r a c t: We often wonder why some individuals become entrepreneurs and others do not? What makes them different from each other? Whether the entrepreneurial sense is innate or the development of entrepreneurial ability is significantly influenced by the external environment. It may be true that some people are born with an entrepreneurial cord or ability, which is then encouraged or hindered by the environment. It is important for the entrepreneur to do his job with real joy not for money or fame, but for real pleasure. Thus, the advantages of entrepreneurship outweigh the difficulties and setbacks that are occasionally present in the entrepreneurial process. The comparison between the research of the entrepreneurial profile of the Macedonian agro-entrepreneur in 2007, with our research conducted in 2019 did not show a significant difference.
\end{abstract}

Key words: entrepreneurship; agri-enterpreneur; entrepreneurial profil; motivation; entrepreneurial ability

\section{ПРЕТПРИЕМАЧКИ ПРОФИЛ НА МАКЕДОНСКИОТ АГРОПРЕТПРИЕМАЧ}

\begin{abstract}
А п с т р а к т: Честопати се прашуваме зошто некои поединци стануваат претприемачи, а други не. Што е тоа по што едните се разликуваат од другите? Дали претприемачката „жичка“ е вродена или, пак, на развојот на претприемачката способност значајно влијае надворешната околина. Можеби е вистина дека некои луѓе се раѓаат со претприемачка жичка или со способност, која потоа околината ја поттикнува или ја кочи. Значајно е претприемачот да ја врши својата работа со вистинска радост не заради пари или слава, туку заради вистинско задоволство. Така, предностите на претприемаштвото преовладуваат над тешкотиите и падовите што повремено се присутни во претприемачкиот процес. Споредбата помеѓу истражувањето на претприемачкиот профил на македонскиот агропретприемач во 2007 година со нашето истражување спроведено во 2019 година не покажа позначајна разлика.
\end{abstract}

Клучни зборови: претприемаштво; агропретприемач; претприемачки профил; мотивација; претприемачка способност

\section{INTRODUCTION}

We often wonder why some individuals become entrepreneurs and others do not? What makes them different from each other? Whether the entrepreneurial sense is innate or the development of entrepreneurial ability is significantly influenced by the external environment [2].

Numerous researches try to determine how entrepreneurship is related to the personality of the entrepreneur. Many entrepreneurship experts offer ways to test a person's entrepreneurial abilities. However, we cannot say with certainty that someone who has successfully solved a certain questionnaire about entrepreneurial skills would surely succeed in the world of entrepreneurship. Also, and vice versa, it is not good to claim that someone who did not solve the same questionnaire successfully, means that he would not succeed in entrepreneurship. The question logically arises why do we conduct such research at all, when they do not give us real answers? We implement them because, on the 
contrary, they give us an answer to the question of who is better and who is lesgood for entrepreneurship. When someone decides to be an entrepreneur, his success (failure), in addition to his abilities, is influenced by other factors: environment, support from the state, friends, health, business opportunities, market situation and so on [3].

It may be true that some people are born with an entrepreneurial cord or ability, which is then encouraged or hindered by the environment. It is important for the entrepreneur to do his job with real joy not for money or fame, but for real pleasure. Thus, the advantages of entrepreneurship outweigh the difficulties and setbacks that are occasionally present in the entrepreneurial process.

The characteristics of the entrepreneur are expressed in three main forms:

- as ability and predisposition (when the entrepreneur can do),

- as knowledge, skill, habit (when the entrepreneur knows how to do),

- as motivation (when the entrepreneur wants to do).

The success of the entrepreneur depends on three interrelated factors, which we can present in the form of the following form [1]:

$$
S E=E A \times E K \times M E
$$

$$
\begin{aligned}
& S E=\text { success of the entrepreneur } \\
& E A=\text { entrepreneurial ability } \\
& E K=\text { entrepreneurial knowledge } \\
& M E=\text { motivation for entrepreneurship }
\end{aligned}
$$

The better developed the entrepreneurial ability, entrepreneurial knowledge and motivation of the individual, the greater the success of the entrepreneur. For example, with better developed entrepreneurial skills, equal level of entrepreneurial knowledge and slightly less motivation for entrepreneurship, the success of the entrepreneur is equal, that is, the lack of one component is compensated by increasing the other and the success of the entrepreneur remains the same. It is important to note that a successful entrepreneur is one who, in addition to the high degree of all three components, has the ability to successfully use his knowledge, ability and experience in practice.

Commonly known entrepreneurial qualities and abilities are innovation, creativity (which does not always bring exceptional results, but - as we know - is a creative process), self-awareness, ambition, determination, perseverance, customer focus, risk attitude (successful entrepreneurs really study it every risk and the same attracts them, but they know when to avoid it and when to accept it), good organizational skills and experience. It is not enough for the entrepreneur to be able to manage his activity and react to the opportunities, but he must be able to anticipate the changes and create entrepreneurial opportunities. The entrepreneurial ability to approach the problem from different angles is also important, which enables it to make different solutions to the problem. In order to avoid rigidity in the way they work, entrepreneurs, above all, must be extremely ethical and businesslike. Independent entrepreneurship is not for everyone. Not every individual can stand such a rhythm of work and life.

For the entrepreneur, the most important are the features that the developed business world is looking for today. It is considered that the most important qualities of an entrepreneur are honesty, fulfillment of promises, diligence, respect for the interests of others, respect for co-workers, etc. The entrepreneur differs from the manager in his gift of recognition (market) and obedience (people's needs). These are two qualities with which he strengthens his knowledge, and at the same time enables him to discover his great business opportunity. Thus, the entrepreneur gets to know the environment in a creative way and connects all the previously known things with the newly created situations.

The answer to the questions: What must a person be to become an entrepreneur? What qualities must have an entrepreneur? Are we born as an entrepreneur or can entrepreneurship be learned? There are important traits that entrepreneurs, venture capitalists, psychologists and professors believe are essential to achieving business success. It is unlikely that someone with all the traits developed extremely strongly or extremely poorly.

The characteristics of the entrepreneur are given in the following Table 1 [4].

There are six golden rules for entrepreneurs. The entrepreneur is indeed a hero, but he is also a victim in his own way and must follow certain rules:

Rule 1: Get to know yourself! Entrepreneurs often do not know enough about themselves. This can be dangerous because it reduces his chances of success. He must be honest and must know what he can and cannot do, what problems he can answer and what he cannot. 
Table 1

Characteristics of the entrepreneur

\begin{tabular}{|c|c|}
\hline Continuous goal setting & Desire for creativity \\
\hline Perseverance & Long-term involvement \\
\hline Business knowledge & Self esteem \\
\hline Facing failure & Undertaking commitments \\
\hline Self-determination & Innovation \\
\hline Moderate risk taking & Long-term visions \\
\hline Continuous problem solving & Positive orientation \\
\hline Initiative & $\begin{array}{l}\text { Technical and industrial } \\
\text { knowledge }\end{array}$ \\
\hline Vigor & Interpersonal relationships \\
\hline Physical health & $\begin{array}{l}\text { Availability of financial } \\
\text { resources }\end{array}$ \\
\hline Mental and emotional health & Desire for money \\
\hline Patience in uncertainty & Ability to think \\
\hline Use of feedback & Ability to sell \\
\hline $\begin{array}{l}\text { Acting in accordance with } \\
\text { personal standards }\end{array}$ & Boldness \\
\hline $\begin{array}{l}\text { Acceptance of personal } \\
\text { responsibility }\end{array}$ & Communication ability \\
\hline Self-awareness & Achievement orientation \\
\hline Desire for independence & Ethical background \\
\hline Use of positive energy & Family background \\
\hline Thoughtfulness of goals & Employee support \\
\hline Objectivity & Education \\
\hline Desire to consult with experts & Flexibility \\
\hline
\end{tabular}

Rule 2: Be comprehensive! It must always be clear to him that things should be completed and not left unfinished.

Rule 3: Be consistent! As temperamental as he is, as difficult and unpredictable as he is, he must try to respond consistently to given situations so that the environment can guess what his reactions would be and conform to them. With such behavior he will gain the respect of his co-workers.

Rule 4: Minimize the consequences of your failures! Failure is an integral part of life. He will always face him to a greater or lesser extent. It is important to know how to lose, to react in time and to start new activities immediately, to make changes and not to be afraid of them.
Rule 5: Look for new roads! There are certain moments in the career of an entrepreneur when he comes to a crossroads and he must understand that, to know that he has to decide which path to choose. Thus, for example, these are the moments when the most important decisions are made: the moment when the idea is chosen, when it increases production, further, when it makes the decision for internationalization of the business, for qualified management and so on. Probably one of the most important decisions is when he should completely or partially withdraw from the business and delegate his powers to the managers, in order to enable full expansion of the business.

Rule 6: Be ready for change! This is probably the most difficult, but also the most important of all the rules. It is constantly emphasized that only change is eternal. Progress depends only on change - change in attitudes, change in knowledge, changes based on new scientific and technological achievements, changes based on new market signals, changes for which knowledge is gained based on experience, changes based on examples from successful enterprises.

\section{MATERIAL AND METHODS OF WORK}

The purpose of this research is based on literature, documents and especially on the analysis of the Questionnaire on a random sample of 64 agro-entrepreneurs from RNM. The research uses several methods used in social and economic analysis such as: generalization and specialization, induction and deduction, statistical and comparative method.

Also, as an imperative of our research is to compare the results of Kostadinov, Nikolova, Cilev G. [5] with our results obtained on the same research in 2019 for the entrepreneurial profile of the Macedonian agro-entrepreneur.

\section{ANALYSIS AND DISCUSSION}

The basis of the survey analysis is the breakdown of data in order to investigate the structure and interdependencies of the factors as a whole.

The first part of the questionnaire refers to determining the success of the entrepreneur (entrepreneurial profile) and contains 18 questions, which refer to entrepreneurial skills, entrepreneurial knowledge and motivation for entrepreneurs. The Mancuso scale was used to evaluate individual responses. 
The questions for determining the entrepreneurial profile are divided into three groups: tion,

- issues related to entrepreneurship motiva-

- issues related to entrepreneurial ability, ledge.

- questions related to entrepreneurial know-

In the questions related to the motivation for entrepreneurship, the respondents express their desires and needs, why they were motivated, i.e. opted for entrepreneurship. In the questions that refer to their abilities, they express their innate and acquired personal qualities, as well as the questions that refer to the entrepreneurial knowledge where the respondents show their level of knowledge. Some questions relate to both entrepreneurial motivation and entrepreneurial skills, and other questions relate to entrepreneurial skills and entrepreneurial knowledge

In the research, the success of the entrepreneur, according to Mancuso is divided into four profiles:

a) A successful entrepreneur is a person who has extremely well-developed entrepreneurial skills, has great entrepreneurial knowledge and experience, and is extremely motivated for entrepreneurship. He is an extremely successful person in business,

b) Entrepreneur is a person who has developed entrepreneurial skills, has entrepreneurial knowledge and experience, and is motivated for entrepre- neurship. However, not all categories are developed to such an extent that it is consistently successful, and therefore also suffers defeats,

c) A potential entrepreneur is a person who has opportunities and potentials to develop entrepreneurial skills and gain entrepreneurial knowledge and experience, but lacks an entrepreneurial environment that would encourage him to do so. The potential entrepreneur, above all, lacks motivation for entrepreneurship,

d) A non-entrepreneur is a person who has no developed entrepreneurial predispositions and finds it difficult to develop them.

We determined the success of the entrepreneur (entrepreneurial profile) by the same method as Plut, who, combining the knowledge of Bujas and Mancuso, claims that the success of the entrepreneur depends on the product of three interrelated factors, which can be represented as follows:

$$
S E=E A \times E K \times M E
$$

$S E=$ success of the entrepreneur;

$E A=$ entrepreneurial ability

$E K=$ entrepreneurial knowledge

$M E=$ motivation for entrepreneurship

The limits of individual profiles of entrepreneurial factors are determined by 50, 66 and 83 percent of the maximum possible points for individual entrepreneurial factors, shown in Table 2.

Table 2

Limits of entrepreneurial factors

\begin{tabular}{llllll}
\hline $\begin{array}{l}\text { Entrepreneurial } \\
\text { ability }\end{array}$ & $\begin{array}{l}\text { EA } \\
(\%)\end{array}$ & $\begin{array}{l}\text { Entrepreneurial } \\
\text { knowledge }\end{array}$ & $\begin{array}{l}\text { EK } \\
\text { (in\%) }\end{array}$ & $\begin{array}{l}\text { Entrepreneurship } \\
\text { motivation }\end{array}$ & $\begin{array}{l}\text { EM } \\
\text { (\%) }\end{array}$ \\
\hline Very capable & (from 83 to 100) & Great knowledge & (from 83 to 100) & Very motivated & (from 83 to 100) \\
Capable & (from 66 to 82) & There is knowledge & (from 66 to 82) & Motivated & (from 66 to 82) \\
Less capable & (from 50 to 65) & Less knowledge & (from 50 to 65) & Less motivated & (from 50 to 65) \\
Incompetent & (from 0 to 49) & There is no knowledge & (from 0 to 49) & Unmotivated & (from 0 to 49) \\
\hline \hline
\end{tabular}

The value of the entrepreneurial ability factor is the sum of the corresponding answers divided by 120.

The value of the entrepreneurial knowledge factor is the sum of the corresponding answers divided by 40 .
The value of the entrepreneurial motivation factor is the sum of the corresponding answers divided by 50 .

The product of the three coefficients gives the index of the entrepreneurial profile. It is shown in the Table 3 . 
Table 3

Entrepreneurial profile boundary index

\begin{tabular}{ll}
\hline \hline Entrepreneurial profile & $S E=E A \times E K \times E M$ \\
\hline Successful entrepreneur & from 0.58 to 1.00 \\
\hline Entrepreneur & from 0.29 to 0.57 \\
\hline Potential entrepreneur & from 0.13 to 0.29 \\
\hline Non-entrepreneur & from $0 \quad$ to 0.12 \\
\hline \hline
\end{tabular}

Based on our research, we can conclude that the differences in the entrepreneurial profile of the Macedonian agro-entrepreneur (synthesized as entrepreneurs and less entrepreneurs) between the research in 2007 and our research did not show a significant difference (Table 4).

Table 4

Comparative analysis by years

\begin{tabular}{lcc}
\hline \hline & $\begin{array}{c}\text { Entrepreneurs } \\
\%\end{array}$ & $\begin{array}{c}\text { Less entrepreneurs } \\
\%\end{array}$ \\
\hline Research 2007 year. & 34.0 & 66.0 \\
Our research 2019 year. & 36.0 & 64.0 \\
\hline \hline
\end{tabular}

\section{CONCLUSION}

The comparison between the research of the entrepreneurial profile of the Macedonian agro- entrepreneur in 2007, with our research did not show a significant difference.

As a conclusion and recommendation for the development of entrepreneurs and entrepreneurship in the agricultural sector, we should certainly suggest the practice of young entrepreneurs in real businesses. Thus, we suggest to intensify the cooperation between education, especially in areas that are central and close to the agro-sector and the agrobusiness sector in all levels of education. In doing so, we will emphasize that learning about entrepreneurship should be introduced as a separate subject, and specialized subjects should be linked to entrepreneurial activities and the benefits of entrepreneurship should be emphasized. In addition, as part of lifelong learning to create general and specialized training in entrepreneurship and management for businesses in the agro sector.

\section{REFERENCES}

[1] Brockhaus, R., Horowitz, P. (1997): The Psychology of the enterpreur. V. Sexton, D. Smilor: The Art and Science of Entrepreneurship. Cambridge.

[2] Frederic, D. (2000): The Psychology of the Entrepreneur. Prentice Hall.

[3] Jonson, B.: Toward a Multidimensional Model of Entrepreneurship. Prentice Hall (1990).

[4] Krebs D. (1990): A Course of Microeconomic Teory, New York, Prentice Hall.

[5] Kostadinov, T., Nikolova N., Cilev G. (2008):The impact of the Enterpreneurial Profile Upon The Export of Agricultural SMEs in the Republic of Macedonia, Proceedings of the International Conference for Enterpreneurship, Innovation and Regional Development, Skopje\&Ohrid, pp 252-257. 
